\title{
Quality of Drinking Water in the Town of Manta in Benin Republic
}

\author{
Kelome Nelly Carine \\ University of Abomey-Calavi, Laboratory of Geology, \\ Mines and Environment (LaboGME), Benin \\ Chouti Waris \\ University of Abomey-Calavi, Chemistry Department, \\ Laboratory of Inorganic Chemistry and the Environment, Benin \\ Lawani Rébecca Annick Niréti \\ Olou Pélagie \\ University of Abomey-Calavi, National Water Institute, \\ Laboratory of Applied Hydrology, Benin
}

\section{Doi: 10.19044/esj.2018.v14n2p188 URL:http://dx.doi.org/10.19044/esj.2018.v14n2p188}

\begin{abstract}
The current research was undertaken in the north of Benin Republic, to assess the pollution level of drinking water; with an emphasis on water sources (boreholes, wells, surface water, and fountain post) and water storage by households. To this end, five villages of the town of Manta were the target. The methodology was based on chemical and bacteriological analyses of water samples collected in October 2015, from ten water sources and four households. The results of chemical analyzes, revealed that two out of five (5) boreholes sampled, had higher than normal nitrate concentrations. Two (2) wells out of three (3) had high ammonium concentrations. As far as the bacteriological aspect is concerned, water from the boreholes and wells are contaminated with fecal germs (Escherichia coli and fecal streptococcus). There is also a large presence of mesophilic aerobic germs and coliform flora in all samples. On the other hand, lithological data from drill holes, in the study area, indicate a preponderance of various schist and alterites that are depleted of fluorides and phosphate compounds. The geological cross-section shows that the aquifer in the town seems to be very homogeneous and does not indicate any tectonic structure that could explain contamination due to horizontal flow. This contamination reflects the lack of hygiene and sanitation near water storage points, the uncontrolled use of pesticides and fertilizers. The use of water protection equipment and hygiene awareness will considerably reduce pollution at the household level.
\end{abstract}


Keywords: Boukombé town, drinking water, pollution, physical chemistry and bacteriological analysis

\section{Introduction}

Water is an essential element in human life as well as in all other living things (Lagnika et al., 2014). It represents $70 \%$ of the human body weight and facilitates the functioning of the body. But it is increasingly polluted and poses a threat to public health (Soro et al., 2010; Ahoussi et al., 2010 and 2012; Eblin et al., 2014). Degradation of water quality usually leads to hygienic risks, transmission of waterborne diseases and cause an obstacle, to economic and social development (Patrice et al., 2006; Ernest et al., 2008). About $80 \%$ of diseases in developing countries and high infant mortality are due to poor water quality (UNICEF, 2002). 1.1 billion of people, do not have access to drinking water and 2.4 billion do not have access to an adequate sanitation (OMS, 2011). More than 2 million people, especially children under five years, in developing countries with insufficient hygiene and sanitation, die each year from diarrhea diseases (OMS, 2011).

In Benin Republic, the accessibility of drinking water continues to be a concern for a large part of the population. The target for 2015 was to provide water to 80 per cent of the population, with 60 liters per day for each inhabitant in urban areas and 10 to 20 liters per day, for each rural resident. To this end, the proportion of the population using an improved source of drinking water, increased from $50 \%$ in 1990 to $57.8 \%$ in 2001. At the national level, this proportion rose from $63.6 \%$ in 2006 to $71.3 \%$ in 2011 (Mendes, 2013). Despite this significant progress, there is a strong geographical disparity and unequal access to water infrastructure (UNDP, 2011), especially, in the populations of remote and disadvantaged areas. Then, these populations are forced to use other water sources, whose quality is often unclear.

This is the case of population of Boukombé, a town in Atacora department, where access to drinking water is below the commitment for the entire country by 2015 . The average coverage rate of this town is $33.1 \%$ (PCEAU Boukombé, 2015). This rate does not match the standard of 250 inhabitants per water point as defined by the National Strategy of Drinking Water Supply document (DGH, 2005). These statistics hide a serious problem of geographical disparity and reliability of sources of supply. In addition, the problems of sanitation and insalubrity are becoming acute in the town of Boukombé. The management of household waste and wastewater is not structured. These wastes are dumped in the wild, most often near dwellings. However, these wastes may contain pollutants that are not only harmful to health, but also could contaminate water resources (Adjia et al., 2008; Adefemi and Awokunmi, 2009; Awokunmi et al., 2010). In addition, cropping techniques such as the inappropriate use of chemical fertilizer and herbicide 
could be a potential source of water pollution and a new challenge facing drinking water supplies. The main objective of this work is to study the level of impairment in the quality of water consumed in the Manta town from sources (boreholes, wells, fountains, surface water) to households (storage).

\section{Materials and methods}

\section{Study environment}

This study was conducted in the town of Manta. It is located in the municipality of Boukombé and is one of its seven (7) town. It has the same physical and climatic characteristics as those observed throughout the Boukombé municipality. The town of Manta is located to the south of the municipality and represents $21 \%$ of its surface area $\left(217.5 \mathrm{~km}^{2}\right)$. The SudanoGuinean climate is characterized by a rainy season from April to October and a dry season from November to March. The hydrographic network of the town of Manta is composed of several streams, quasi-permanent rivers and some ponds. Around these pools, rice, yam, cassava and market gardening are established. The town's water supply rate is $37.3 \%$ (PCEAU Boukombé, 2005).

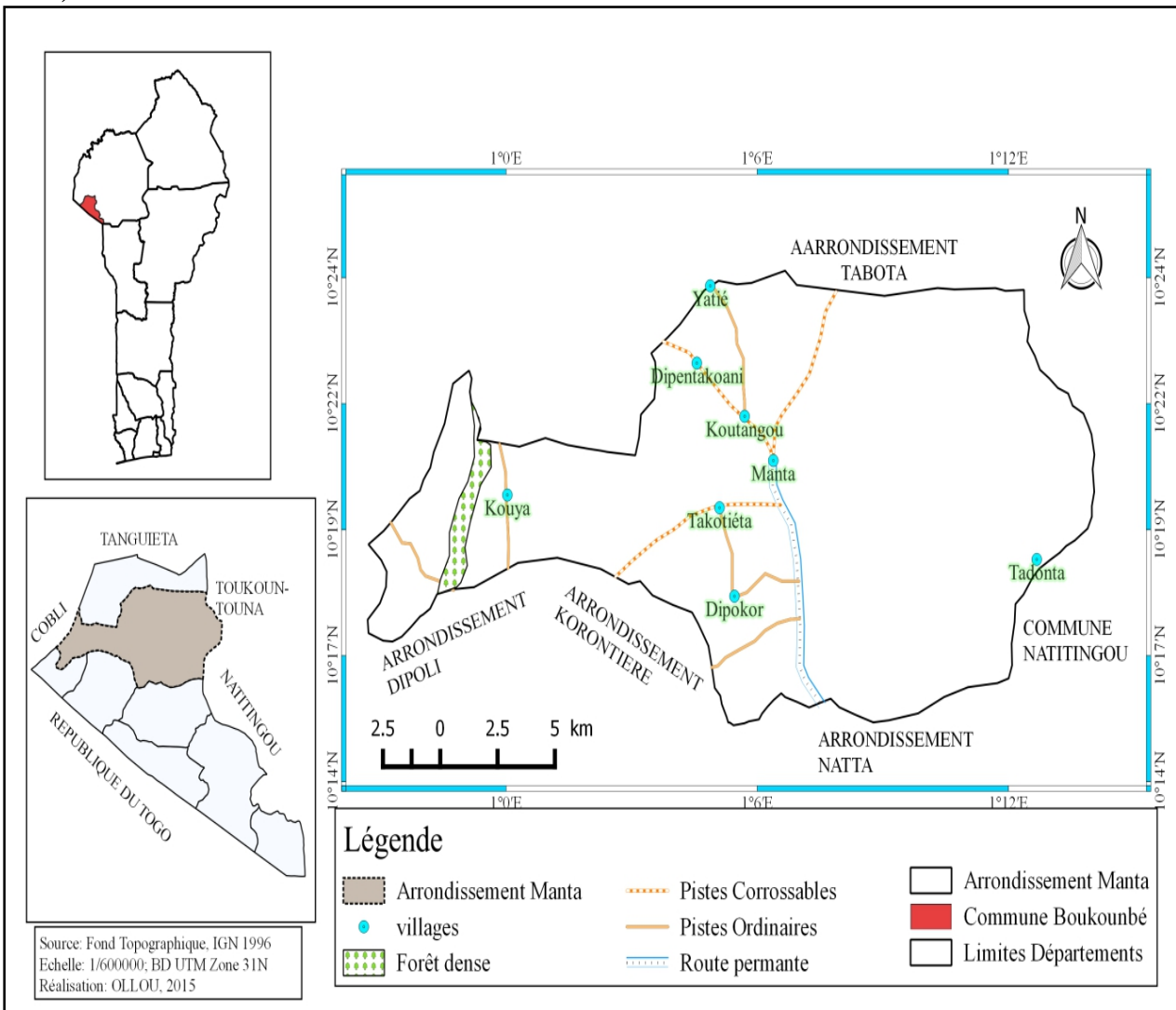

Figure 1: Location map of the town of Manta 
The town of Manta is a vast peneplain based largely on Pordiéga and Kande-Boukombé sets. The Atacorian is mainly composed of an important base of quartzite and inter-stratified mica schist, usually found in the Atacora talwegs. The reliefs are oriented north-south with to the east, the last link of the chain of the Atacora (Affaton, 1975).

\section{Material}

The material used for this study is divided into two categories: field equipment and laboratory equipment. The equipment used in the field consists of sampling bottles, a cooler, a gas pistol, a GPS (Garmin 72), a digital camera (Casio 500), a notebook and a motorcycle. The equipment used in the laboratory includes a table autoclave (Varioclav 75T, H + P), a sterilizer (Heraeus), a magnetic stirrer (Ikamag Reo), a heating plate (Ika Labortechnik, Type RET B), a precision scale (Sartorius-Werke), pipettes and micropipettes, glassware, reagents and culture media, petri dishes, spatulas, aluminum papers etc ....

\section{Methods}

The general methodology of this study is structured around four main phases: the survey phase, the sampling phase, the analysis phase and the data interpretation phase.

\section{Investigation}

The survey consisted of collecting information from women, about the different sources of water supply, conservation methods and average residence time of these waters in the households. Information on available water supplies, and projections of needs by 2017, was collected from the town. Information on the cultivation practices in the town and the use of chemical fertilizers in agriculture--was obtained from the farmers. There is also direct observation of some water points. This information allowed evaluating the measures taken by the population to protect and clean up the water.

\section{Selection of the sampling sites}

The selection of the sampling sites was made by a random method. It consisted of randomly drawing a card for a village in the town of the study. Five boreholes with artificial lift system were selected in five villages (Figure 2). 


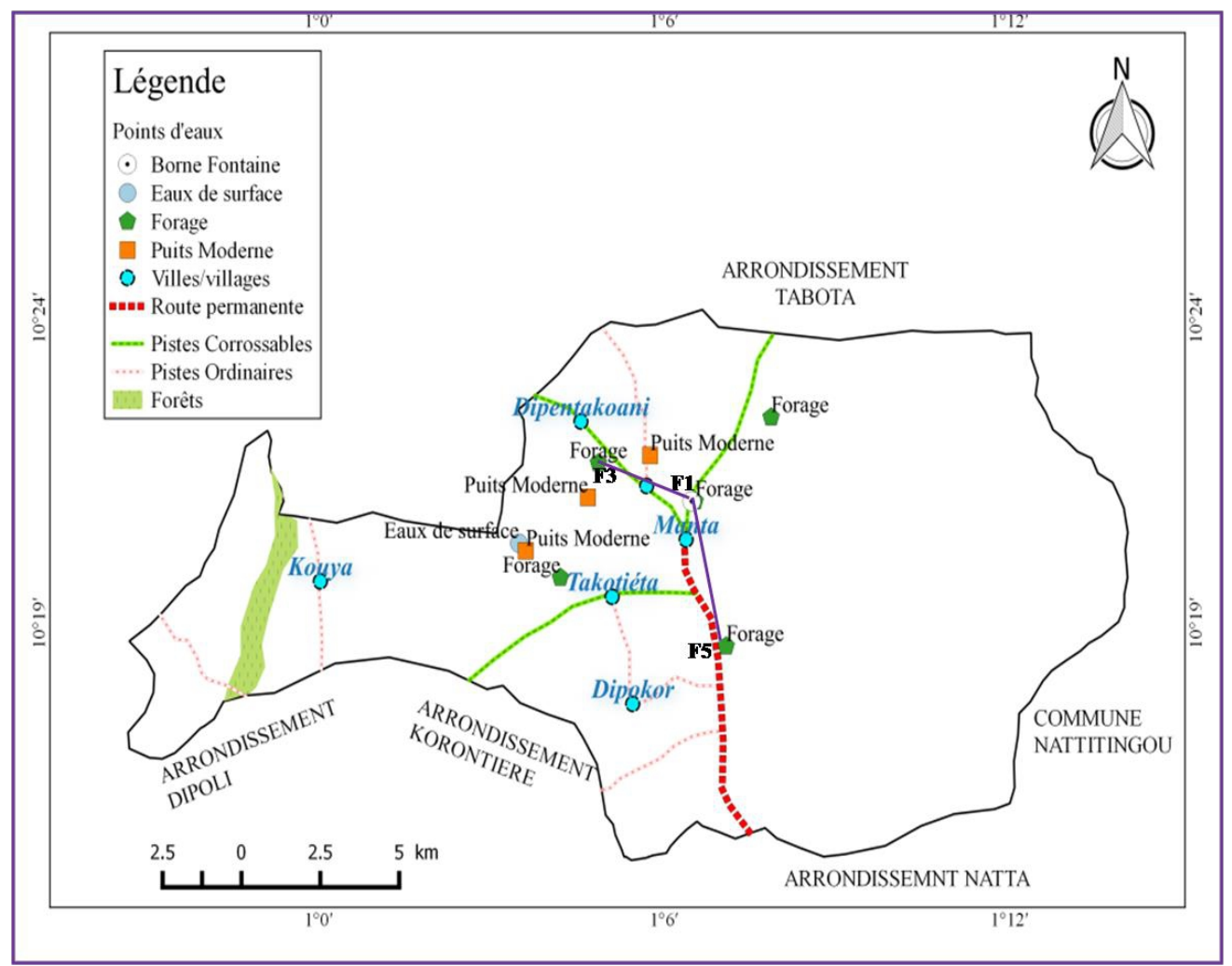

Figure 2: Spatial distribution map of samples and cut lines F3, F1 and F5

\section{Sample collection method}

Two samples were taken at each water point: one for physical and chemical analysis and the other for bacteriological analysis. A single sample was taken at the household level, for bacteriological analysis. The sampling of a water for physical, chemical and bacteriological analyzes is an operation requiring rigor and care, as it determines the analytical results and consequently its interpretation. Table 1 shows the coding of the samples and the characteristics of the sampled hydraulic structures.

Table 1: Samples designation

\begin{tabular}{|c|c|c|c|c|}
\hline Villages & Source Types & Sample code & $\begin{array}{c}\text { Depth of } \\
\text { structure }(\mathrm{m})\end{array}$ & The Aquifer \\
\hline Koutangou & Borehole & F1 & 44 & $\begin{array}{c}\text { Schists with quartz } \\
\text { and sericite }\end{array}$ \\
\cline { 2 - 5 } & Well & P1 & - & - \\
\cline { 2 - 5 } & Fountain post & BF & - & - \\
\cline { 2 - 5 } & Household & M1 & - & - \\
\hline Koumadogou & Borehole & F2 & 47.55 & $\begin{array}{c}\text { Schist with } \\
\text { chloritized quartz }\end{array}$ \\
\cline { 2 - 5 } & Household & M2 & - & - \\
\hline
\end{tabular}




\begin{tabular}{|c|c|c|c|c|}
\hline Dikouténi & Borehole & F3 & 55.62 & $\begin{array}{c}\text { Chloritized quartz } \\
\text { schists }\end{array}$ \\
\cline { 2 - 5 } & Well & P3 & - & - \\
\cline { 2 - 5 } & Household & M3 & - & - \\
\hline \multirow{3}{*}{ Dikon - Hein } & Borehole & F4 & 43 & Schists and argillite \\
\cline { 2 - 5 } & Well & P4 & - & - \\
\cline { 2 - 5 } & Surface water & ES & - & - \\
\cline { 2 - 5 } & Household & M4 & - & Sandstone schist \\
\hline Dipokor II & Borehole & F5 & 73.8 & \\
\hline
\end{tabular}

Sample analysis methods

Physical parameters

Physical parameters include temperature, conductivity and $\mathrm{pH}$. They are measured directly using a German Multimeter of the Multi 3420 Set type.

\section{Chemical parameters}

The chemical parameters determined in this study are ammonium $\left(\mathrm{NH}_{4}{ }^{+}\right)$, nitrates $\left(\mathrm{NO}_{3}^{-}\right)$, nitrites $\left(\mathrm{NO}_{2}^{-}\right)$, fluorides $\left(\mathrm{F}^{-}\right)$and phosphates $\left(\mathrm{PO}_{4}{ }^{2-}\right)$. The analytical methods used are, on the one hand, the comparison method for the determination of nitrate and, on the other hand, the spectrophotometric method for ammonium, phosphate, nitrite and fluoride ions.

\section{The bacteriological parameters}

Four germs have been the subject of bacteriological research. These are Total Coliforms, Escherichia coli, fecal streptococci and total flora. These germs were counted by the bulk seed method (Table 2).

Table 2: Bacteriological research parameters

\begin{tabular}{|c|c|c|c|}
\hline Parameters & Seeding type & Culture medium & Criterion \\
\hline Total Coliforms & $5 \mathrm{ml}$ in the mass & Tergitol 7 lactose agar & $37^{\circ} \mathrm{C}$ in $24 \mathrm{~h}$ \\
\hline E. coli & $5 \mathrm{ml}$ in the mass & Tergitol 7 lactose agar & $44^{\circ} \mathrm{C}$ in $24 \mathrm{~h}$ \\
\hline Streptococci & $5 \mathrm{ml}$ in the mass & Slanetz and Bartley & $44^{\circ} \mathrm{C}$ in $48 \mathrm{~h}$ \\
\hline Total flora & $250 \mu / 1$ in the mass & $\begin{array}{c}\text { PCA (Plate Count } \\
\text { Agar) }\end{array}$ & $37^{\circ} \mathrm{C}$ in $48 \mathrm{~h}$ \\
\hline
\end{tabular}

\section{Data processing}

The results of the physical, chemical and bacteriological analyzes were processed using the Excel spreadsheet. They are then, used for statistical descriptive purposes. The WHO drinking-water quality guidelines were used to interpret the results. 


\section{Results}

\section{Survey results}

The survey allowed inventorying the different sources of drinking water supply in the town of Manta. These are wells, boreholes and surface water. Water from these sources is often collected in basins, that are transported without cover and sometimes, it is collected in cans. Once in households, this water is mostly stored in traditional jars. The average residence times of water in these jars are estimated to be three (3) days. Surveys have also revealed that the immediate environment of the water supply points of the population of the Manta town, suffers from lack of maintenance (Figure 3).

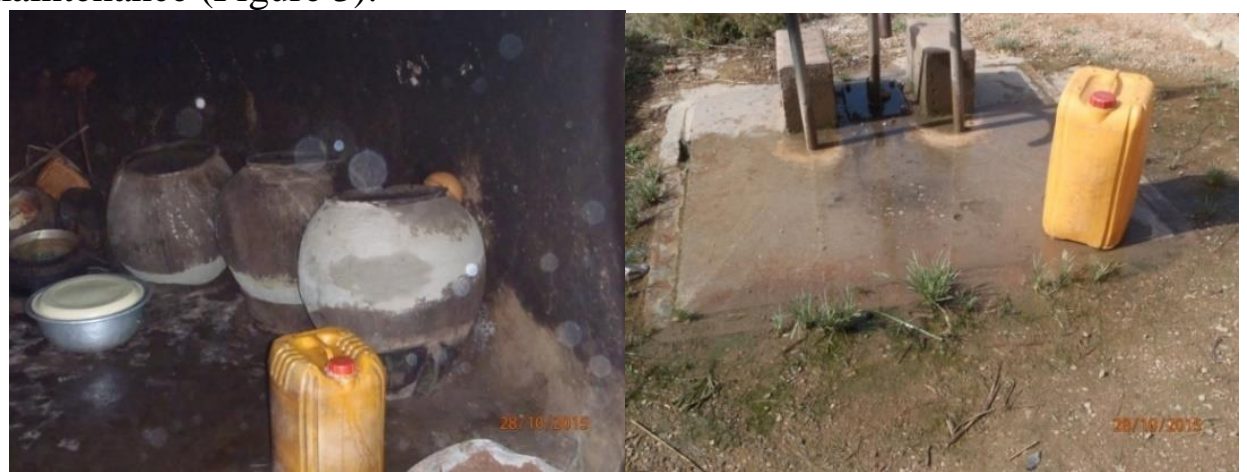

Figure 3: Household water storage conditions and water point's unhealthiness

i. Moreover, the amount of chemical fertilizers admitted by the Regional Agricultural Development Center depends on the number of hectares of cultivated land. For each hectare ( 1 ha) of a cornfield, a total of four (4) bags of fifty (50) kilograms of fertilizer, including one hundred (100) $\mathrm{kg}$ of NPK and $100 \mathrm{~kg}$ of urea, are supplied. The quantity of fertilizer received is, thus, according to the number of hectares of fields declared by the farmer.

\section{Physical parameters}

The three physical parameters measured are $\mathrm{pH}$, electrical conductivity and temperature (Table 3). 
Table 3: Results of physical parameters and the associated WHO Standards

\begin{tabular}{|c|c|c|c|c|}
\hline Sample & Code & $\mathrm{pH}$ & $\begin{array}{c}\text { Electrical Conductivity } \\
(\mu \mathrm{S} / \mathrm{cm})\end{array}$ & Temperature $\left({ }^{\circ} \mathrm{C}\right)$ \\
\hline Borehole & F1 & 7.16 & 307 & 24 \\
\hline Borehole & F2 & 7.33 & 379 & 25.4 \\
\hline Borehole & F3 & 7.75 & 661 & 25.8 \\
\hline Borehole & F4 & 7.61 & 212 & 25.2 \\
\hline Borehole & F5 & 7.31 & 386 & 24.3 \\
\hline Well & P1 & 7.65 & 157.6 & 24.3 \\
\hline Well & P3 & 7.12 & 153 & 26.4 \\
\hline Well & P4 & 7.56 & 137.2 & 25.9 \\
\hline Surface water & ES4 & 7.58 & 61.3 & 25.5 \\
\hline Fountain post & BF & 7.39 & 330 & - \\
\hline \multicolumn{2}{|l}{ WHO Standards } & $6.5-8.5$ & 2000 & \\
\hline
\end{tabular}

This table shows a variation in $\mathrm{pH}$ ranging from 7.12 (Dikouteni well) to 7.65 (Koumadogou well), with an average of 7.44 . The mean conductivity is $278.41 \mu \mathrm{S} / \mathrm{cm}$ with the highest value observed in the Dikouteni borehole and the lowest value in the surface water. The average temperature is $25.34{ }^{\circ} \mathrm{C}$. It appears from the analysis of this table, that all physical parameters measured comply with the World Health Organization (WHO) guidelines for drinkingwater (OMS, 2011).

\section{Chemical parameters Nitrates}

The nitrate concentrations of the samples range from $4.4 \mathrm{mg} / \mathrm{l}$ (Koumadogou drilling) to $52.8 \mathrm{mg} / \mathrm{l}$ (Koutangou drilling). Only the F1 (Koutangou) and F3 (Dikouteni) boreholes have their nitrate values above the WHO standard of $45 \mathrm{mg} / \mathrm{l}$ (OMS, 2006) (Figure 4).
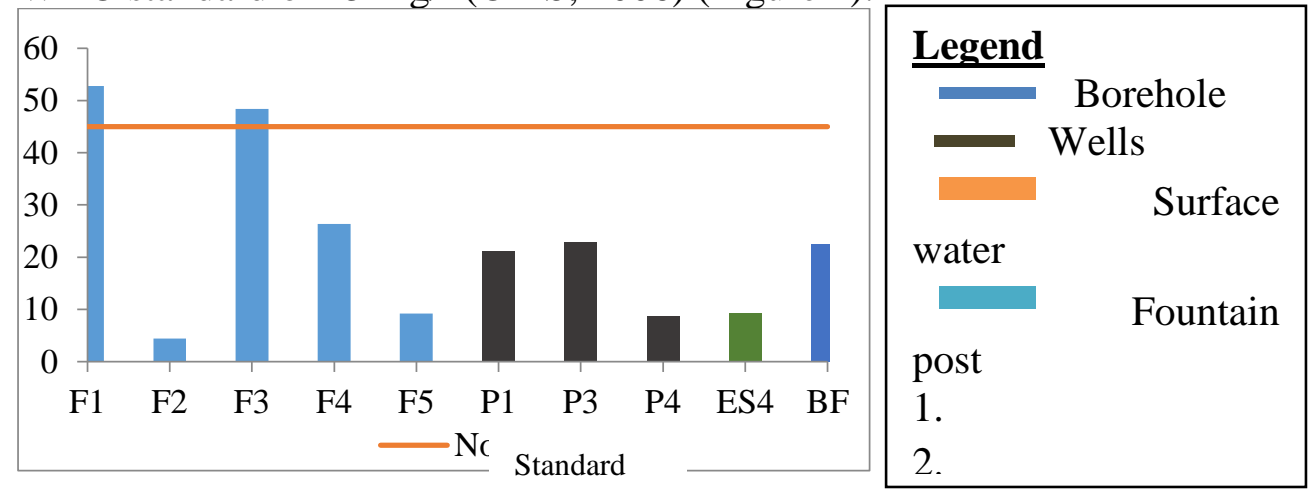

Figure 4: Nitrate variation of sampled water

\section{Ammonium}

Ammonium concentrations ranged from $0 \mathrm{mg} / 1$ for most samples, to 
$1.74 \mathrm{mg} / \mathrm{l}$ for well P3 (Dikouteni) and P4 (Figure 5).

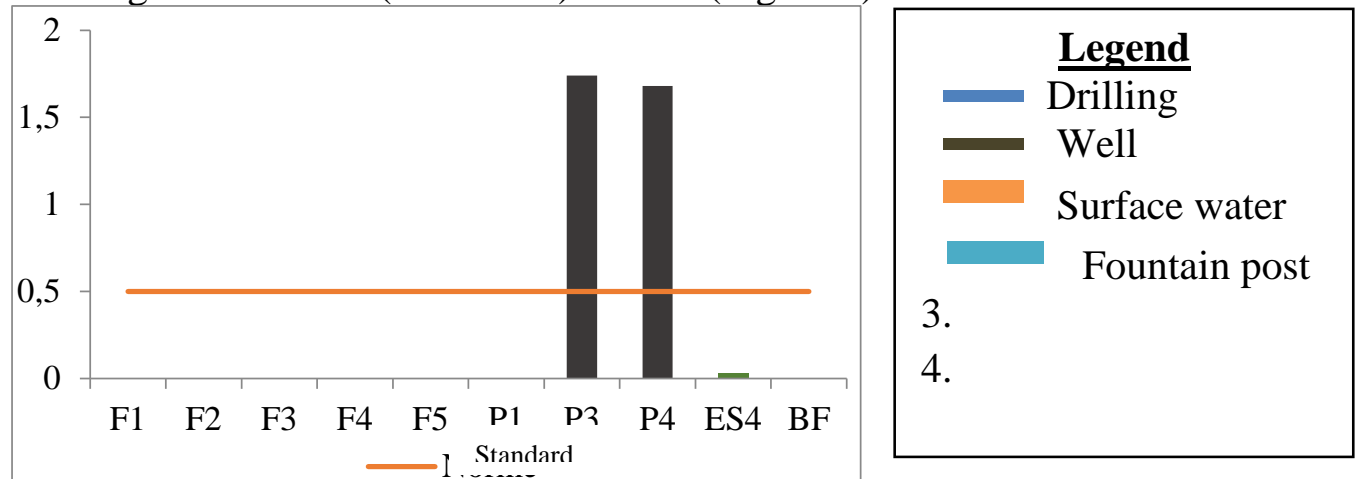

Figure 5: Ammonium variation of sampled water

\section{Phosphate}

Figure 6 shows the variation in phosphate concentrations in the sampled waters. They range from $0.24 \mathrm{mg} / \mathrm{l}$ to $2.4 \mathrm{mg} / \mathrm{l}$. In fact, phosphates are generally responsible for the acceleration of eutrophication phenomena in lakes or rivers (Devidal, 2007).

2.

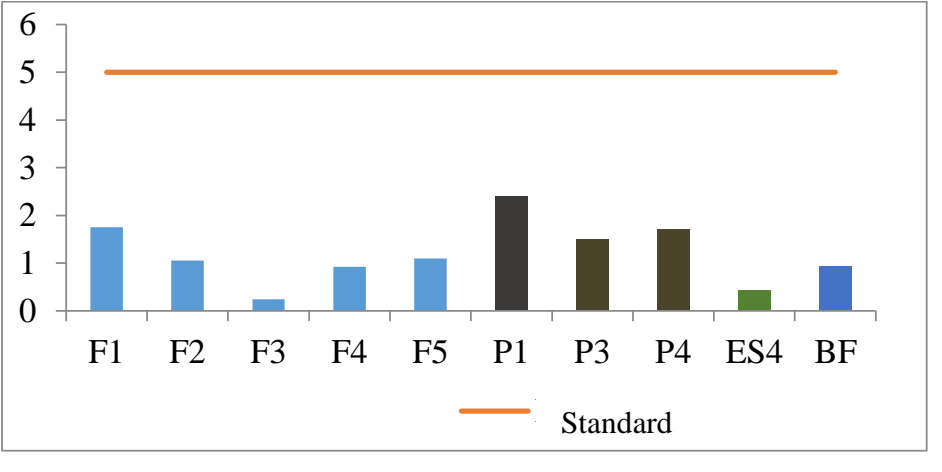

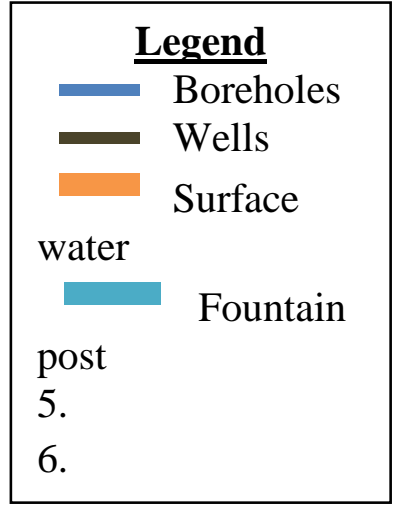

6.

Figure 6: Phosphate variation of sampled water

\section{ii. All values are below the WHO standard. Nitrites and fluorides were also measured in these waters. The concentrations of these ions are close to zero.}

\section{Bacteriological parameters}

All sampled water contain Total Coliforms. Their concentrations range from $320 \mathrm{CFU} / 100 \mathrm{ml}$ (fountain post) to $6320 \mathrm{CFU} / 100 \mathrm{ml}$ (surface water) at the source level and from $940 \mathrm{CFU}$ to $13,760 \mathrm{CFU} / 100 \mathrm{ml}$ in households (Figure 7). According to WHO standards, the most accurate indicator for estimating fecal pollution is Escherichia coli because it is abundant in human faeces. All the waters sampled, outside the fountain terminal, contain E. coli in large quantities. Their average concentration at the source is $250 \mathrm{UFC} / 100$ 
$\mathrm{ml}$ and varies between 20 UFC and 660 UFC (Dikon-hein well and surface water) (Figure 7). In households, the average is $5155 \mathrm{UFC} / 100 \mathrm{ml}$ and range from 120 to $10560 \mathrm{UFC} / 100 \mathrm{ml}$. The standard set by the WHO is $0 \mathrm{CFU} / 100$ $\mathrm{ml}$.

The number of faecal streptococci rangs from $0 \mathrm{CFU}$ (borehole and fountain post) to $1500 \mathrm{CFU} / 100 \mathrm{ml}$ (surface water) at the source level, and from $300 \mathrm{CFU}$ to $13120 \mathrm{CFU} / 100 \mathrm{ml}$ in households. The WHO standard is 0 UFC/100 ml. Fecal streptococci are largely of human origin. They are generally considered as faecal pollution indicators, because all have a fecal habitat. Figure 7 shows a variation of fecal streptococci in the sampled water. Only two water sources sampled out of fourteen have their revival aerobic germ values below the WHO standard of $50 \mathrm{CFU} / \mathrm{ml}$ for non-disinfected water (Figure 7). The mean of mesophilic aerobic germs of spring water is 398 $\mathrm{CFU} / \mathrm{ml}$ ranging from $40 \mathrm{CFU}$ (F2 and $\mathrm{BF}$ ) to $1480 \mathrm{CFU}(\mathrm{P} 4)$. In households, these germs range from 704 (M3) to 3088 (M4) with an average of 1772 $\mathrm{CFU} / \mathrm{ml}$.
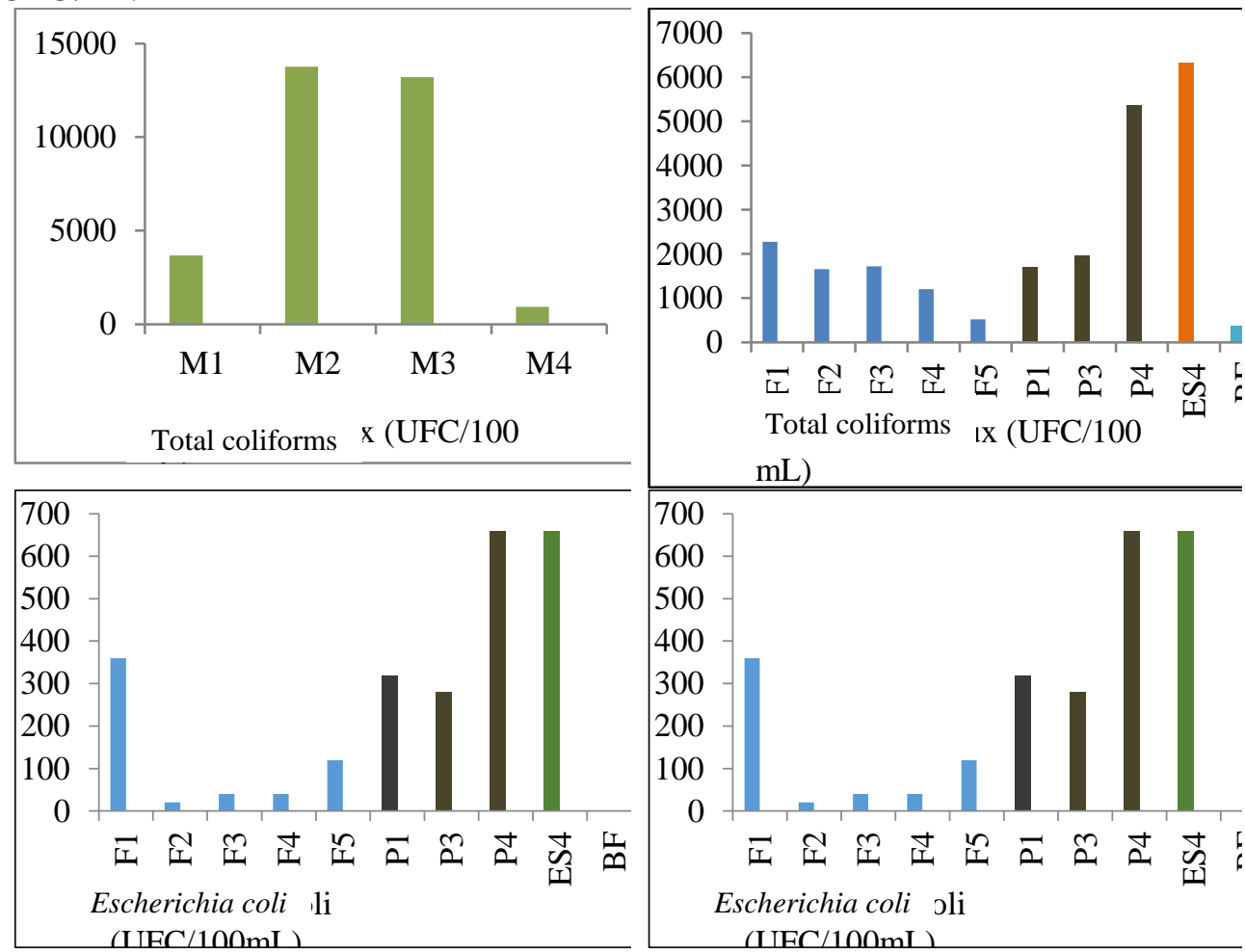


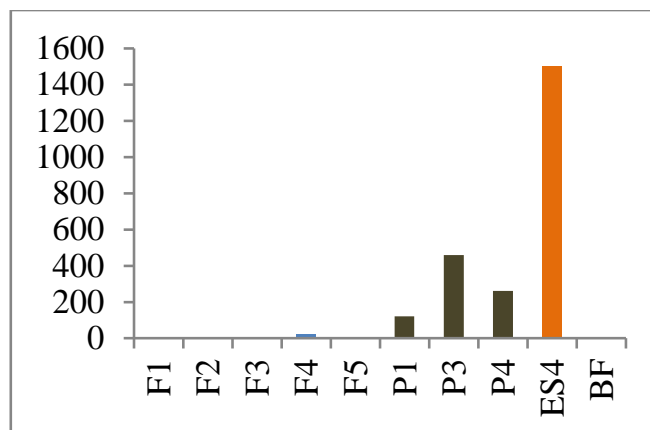

Snectrococc is (UFC/100

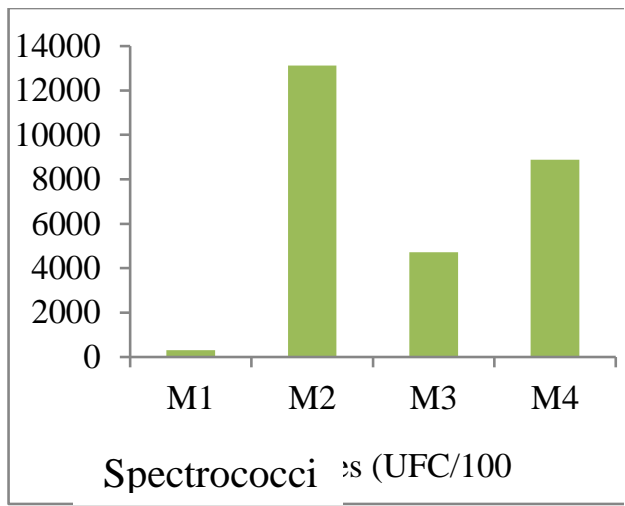

Spectrococci is (UFC/100

Figure 7 : Variation of E. coli, total coliforms, Aerobic Mesophilic germs and Streptococci contained in sampled water

\section{Lithological characteristics of the captured aquifers}

The geological characteristics of the aquifer formations captured may be responsible for the variability of the chemical elements in the water sampled in the hydraulic structures. Figure 8 shows the lithostratigraphic relationship between the formations traversed by the structures F1, F3 and F5.

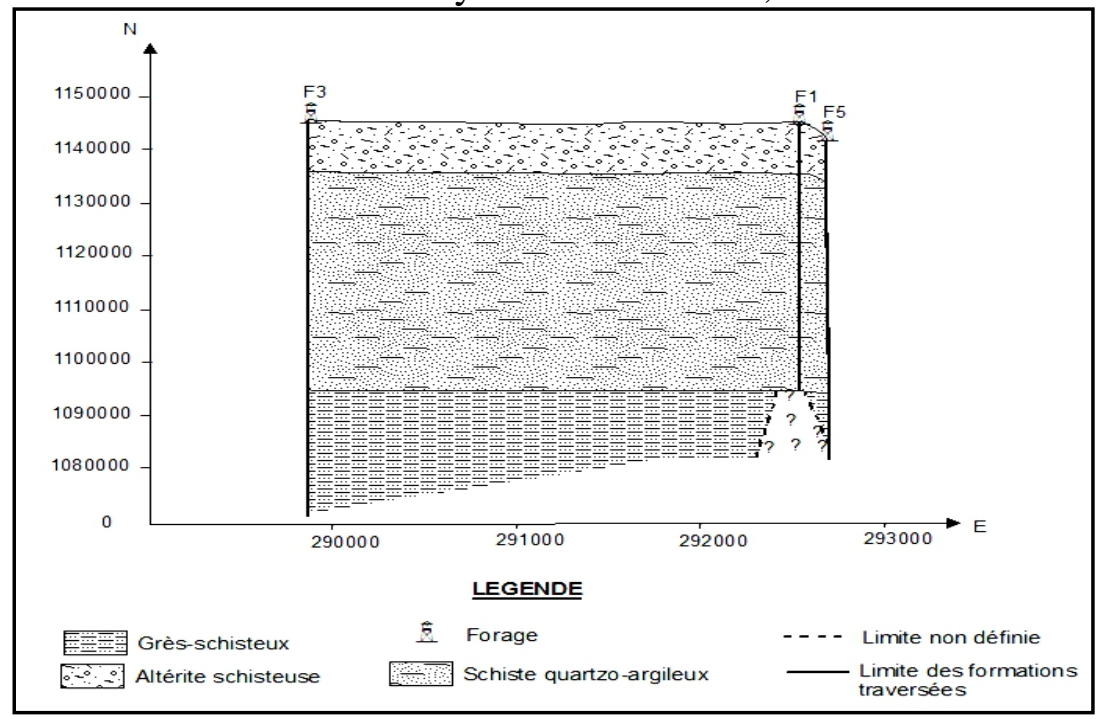

Figure 8: Geological section connecting boreholes F3, F1 and F5

The analysis of this geological section shows an aquifer level marked lithologically by various alterites, represented by clayey schists, quartzous clays, with a static level located in clays of alteration. The aquifer in the study area appears very homogeneous and does not indicate any tectonic structure, which may explain contamination due to horizontal flow. 


\section{Discussion}

The water from different sources has good conductivity values. Except for the conductivity value of surface water, the other values are within the range of the EU/WHO mineralization standard of $150-800 \mu \mathrm{S} / \mathrm{cm}$. These values are lower than those obtained in three thermal spas in the Fez regions of Morocco (Houti et al., 2014). The mean conductivity is $278.41 \mu \mathrm{S} / \mathrm{cm}$, with the highest value observed in the Dikouteni borehole and the lowest value in the surface water. All measured $\mathrm{pH}$ meet the WHO standard of 6.5 to 8.5. This is not the case for well water in the town of Pobè (Benin Republic), where most $\mathrm{pH}$ value is below 6.5 (Lagnika et al., 2011), which does not respect the standard.

The $\mathrm{pH}$ values in the range of 6.5 to 8.5 are recommended as they protect the water collection structures from corrosion or scaling. They also protect consumers from the risk of disease and promote a better taste for water. Temperatures range from 24 to $26.6^{\circ} \mathrm{C}$ with an average of $25.3^{\circ} \mathrm{C}$. This can be explained by the influence of the ambient temperature on the collected water. It should be emphasized that water temperature, between $25^{\circ} \mathrm{C}$ and 28 ${ }^{\circ} \mathrm{C}$, is a good culture medium for microorganisms. This temperature creates favorable conditions for bacteriological contamination.

The results of the chemical analyzes indicate that, except a nitrate concentration of F1 and F3 boreholes, and ammonium concentrations of P3 and P4 wells, all chemical parameters measured in the samples comply with the guidelines of the World Health Organization (WHO) for drinking-water. These results are in agreement with those obtained by Nonfodji (2009) in Djougou on the monitoring of groundwater quality. All the chemical parameters measured in this study comply with WHO standards.

These concentrations of nitrates, phosphates and ammoniums observed may not to be ignored because these elements are organic nitrogen compounds and are considered as good indicators of organic pollution. The study area is made up of sedimentary formations endured (metamorphosed) covered by a thick layer of clays, only vertical fractures (in this case joints and fractures), can explain the local presence of these ions in the boreholes. It is therefore important that complementary studies on a smaller scale be carried out to establish accurately the sources of chemical contaminants observed in the study area. However, the presence of these elements in the environment, although beneficial for plant growth, can cause methemoglobinemia in humans, and unable blood transport to tissues. Indeed, the nitrites obtained after reduction of the nitrate ions by the bacteria of the digestive tract, are responsible for the serious disorders which can cause death by asphyxia (Skold et al., 2011).

Also, too much phosphate can cause eutrophication or overfertilization of streams, especially if large amounts of nitrates are present. It is 
therefore important that special attention be given to the sanitation and use of plant protection products in the town.

Of the ten water sources sampled, only the fountain terminal is free of fecal contamination. All boreholes and wells are polluted with an average of $116 \mathrm{E}$. coli in the boreholes, against 420 colonies in the wells. These results confirm those of Makoutodé et al. (1999) in Grand Popo and those of Nonfodji (2009) in Djougou, where $100 \%$ and $93 \%$ of the wells analyzed are polluted by fecal contamination germs.

These results are also the same with those obtained elsewhere than in Benin Republic: on the Agnébi River in Ivory Coast (Manizan et al., 2010), on source water of the Mangouin-Yrongouin village in Ivory Coast (Ahoussi et al., 2013) and on the groundwater M'nasra in Morocco (Bricha et al., 2007).

However, the results observed in the boreholes are contrary to those of Nonfodji (2009) in Djougou, Lagnika (2011) on the triangle of ParakouDjougou-Bassila; those of Jabu (2007) in Malawi, and those of Dianou et al., (2002) in Burkina Faso. In these studies, an absence of fecal bacteria was observed in the boreholes. Factors related to the poor quality of these waters are mainly the lack of hygiene of the users and the lack of improvement of the immediate environment of certain structures. Also, it was found the failure of the water pumping pedal, at the level of some pedestrian drilling. It sometimes happens that the back pressure, necessary for the rise of the pedal, falls after a prolonged period of inactivity. This fact leads users to pour a good quantity of water previously stored in the households, into the water pipes in order to raise the water in the pipeline. This unhygienic practice does not ensure a good quality of the water. Also, there are almost no toilets in this town. The population defecates in the wild and sometimes near the water points. This behavior could be an important factor in degrading water quality.

Regarding the impact of household storage conditions on water quality, the results of the analyzes show that $100 \%$ of the households visited have their stock of water soiled by fecal pollution germs, $50 \%$ have more than 500 colonies of $E$. coli in their drinking water. Jabu (2007) in two villages in Malawi, found $91 \%$ and $80 \% \mathrm{E}$. coli out of 10 households surveyed. It follows that the methods of storing water suffer from the lack of hygiene. Indeed, the water storage material most often used in the town of Manta is the traditional jar. During storage, water may be contaminated with nests of microbes that form in the roughness of the walls of the tanks. Similarly, intake calabashes are not always clean before they are introduced into jars, which are sometimes left uncovered. The average residence time of water in households is estimated in 3 days, and the renewal does not necessarily imply cleaning of the storage container. Added to this, households raise animals in their concessions. Animal husbandry, especially warm-blooded and wandering animals (cattle, pigs, poultry, etc.) has a negative impact on household water 
quality. All these behaviors are potential factors for contamination of stored water.

The quality of water provided to the population of the town of Manta is a matter of major concern. It can be considered as a threat to public health. It is therefore urgent, that the water supply authorities and those responsible for basic hygiene and sanitation take corrective measures more quickly.

\section{Conclusion}

This work showed a correlation between the field observations and the results of the analysis. It indicated that the drinking water of the town of Manta contained mineral compounds including nitrates and phosphates. These compounds, which can be derived from the use of plant protection products by farmers to enrich the soil, cause damage to the quality of the water consumed by the population. Bacteriologically, $93 \%$ of the structures sampled show a high presence of fecal coliforms and total coliforms, which exceed the limit values recommended by the standards defined by the Benin Republic authorities and the World Health Organization for drinking water. This is mainly due to the lack of hygiene and sanitation in the environment of the water points.

\section{References:}

1. Adefemi S. O. and E. E. Awokunmi, (2009). The impact of municipal solid waste disposal in Ado-Ekiti metropolis, Ekiti-State, Nigeria. Afr. J. Environ. Sci. and Tech. 3 (8):186-189 p.

2. Adjia R., W. M. L Fezeu, J. B. Tchatchueng, S. Sorho, G. Echevarria, M. B. Ngassoum, (2008). Long term effect of municipal solid waste amendment on soil heavy metal content of sites used for periurban agriculture in Ngaoundere, Cameroon. Afr. J. Environ. Sci Techn. 2 (12): 412-421.

3. Affaton P. (1975). Étude géologique et structurale du Nord-Ouest du Dahomey, du Nord du Togo et du Sud-Est de la Haute Volta. Travaux Laboratoire Sciences Terre. (10), 201p. St Jérôme Marseille, France.

4. Ahoussi K. E., Koffi Y. B., Kouassi A. M., Soro G., Soro N., Biémi J., (2012). Étude des caractéristiques chimiques et microbiologiques des ressources en eau du bassin versant du N'zi : cas de la commune de N'zianouan (Sud de la Côte d'Ivoire). International Journal of Biological and Chemical Sciences, 6(4): 18541873.

5. Ahoussi K. E., Soro N., Koffi Y. B., Soro G., Biémi J., (2010). Origine de la minéralisation des eaux des aquifères discontinus sous couvert forestier de la zone Sud de la Côte d'Ivoire: cas de la région d'AbidjanAgboville. International Journal of Biological and Chemical Sciences, 4(3): 782-797. 
6. Ahoussi, K. E., Koffi, Y. B., Kouassi, A. M., Soro, G., Soro, N., \& Biémi, J. (2012). Étude des caractéristiques chimiques et microbiologiques des ressources en eau du bassin versant du N'zi: cas de la commune de N'zianouan (Sud de la Côte d'Ivoire). International Journal of Biological and Chemical Sciences, 6(4), 1854-1873.

7. Ahoussi K. E, Koffi Y. B, Kouassi A. M., Soro G., Biemi J. (2013). Étude hydrochimique et microbiologique des eaux de source de l'ouest montagneux de la Côte d'Ivoire : Cas du village de MangouinYrongouin (sous-préfecture de Biankouman). Journal of Applied Biosciences (63) : 4703 - 4719.

8. Awokunmi E. E., S. S. Asaolu1 and K. O. Ipinmoroti, (2010). Effect of leaching on heavy metals concentration of soil in some dumpsites. Afr. J. of Environ. Sci. Techn. 4(8): 495-499.

9. Bricha S, Ounine K, Oulkheir S, El Haloui N, Et Attarassi B. (2007). Etude de la qualité physicochimique et bactériologique de la nappe phréatique M'nasra (Maroc). Afrique Science 03(3) 391 - 404.

10. Dianou O., Poda J. N., Thiombiano L., Sorgho H., (2002). Qualité des eaux de boisson de forages et des ménages en milieu rural : Cas de Thion, Blédougou et Kangoura au Burkina Faso. Sud sciences \& technologies $9: 25-33$.

11. Devidal S, (2007). Solutions curatives pour la restauration de lacs présentant des signes d'eutrophisation. Mémoire de Master en Environnement de l'Université de Sherbrooke. 51 p.

12. Direction Générale de l'Hydraulique (DGH) (2005). Stratégie nationale d'approvisionnement en eau potable en milieu rural $d u$ Benin 2005-2015. 21p.

13. Eblin S. G., Sombo A. P., Soro G., Aka N., Kambiré O., Soro N., (2014). Hydrochimie des eaux de surface de la région d'Adiaké. J. Appl. Biosci. 75: 6259-6271.

14. Ernest A. K., Nagnin S., Gbombélé S., Théophile L., Solange O. M., Pacôme Z S ., (2008). Groundwater Pollution in Africans Biggest Towns: Case of the Town of Abidjan (Côte d'Ivoire). European Journal of Scientific Research, 20(2): 302-316.

15. Houti A., Benbrahim K. F., El Ouali Lalami A., Zbadi L., Rachiq S, (2014). Qualité physicochimique et bactériologique de trois stations thermales dans les régions de Fès, Maroc. Afrique Science 10(4) 158 168.

16. Jabu G. C., (2007). Assessment and comparison of microbial quality of drinking water in Chikwawa, Malawi. www.csfp.online.org/news/jabupaper.pdf [04-11-15].

17. Lagnika M., (2011). Déterminants du risque de contamination bactériologique des eaux des forages dans les ménages de la Haute 
Vallée de l'Ouémé : cas du triangle Parakou-Djougou-Bassila, Mémoire DESS-MEQUE, UAC Bénin/EPAC, 125p.

18. Lagnika M, Ibikounle M, Montcho J-P C., Wotto D.V., Sakiti N. G., (2014). Caractéristiques physico-chimiques de l'eau des puits dans la commune de Pobè (Bénin, Afrique de l'Ouest). Journal of Applied Biosciences. (79):6887- 6897.

19. Makoutodé M., Assani A. K., Ouendo E. M., Agueh V. D., Diallo P., (1999). Qualité et mode de gestion de l'eau de puits en milieu rural au Bénin : cas de la sous-préfecture de Grand-Popo, Médecine d'Afrique Noire : 46 (11).

20. Mendes J. (2013). Cadre d'accélération des OMD : accès à l'eau potable et à l'assainissement de base. Ministère du Développement, de l'Analyse Économique et de la Prospective (MDAEP) de la République du Bénin, $112 \mathrm{p}$.

21. Nonfodji P., (2009). Suivi de la qualité des eaux souterraines dans la commune de Djougou et les facteurs exogènes de sa pollution, Mémoire de fin d'étude FOAD Master GIRE, 93 p.

22. OMS, (2011). Directives de qualité pour l'eau de boisson. Quatrième édition. Publication Organisation Mondiale de la Santé. Genève, Suisse. 307- 447 pp.

23. Manizan P. N., Konan B, Gourene G, Dosso M., (2010). Dynamique des flux bactériens dans un hydrosystème ouest africain : cas de la rivière Agnébi, Côte d'Ivoire. Afrique Science 06(2) 9 - 17.

24. Patrice J. J., Jean K. K, Bachir S. M, Hélène K. B, Solange O Y., (2006). Contamination of the Abidjan aquifer by sewage: An assessment of extent and strategies for protection. Groundwater Pollution in Africa, Yongxin X, Brent U (eds). Taylor \& Francis/Balkema: Great-Britain; 293-302.

25. PCEAU Boukombé 2015-2017, (2005).Programmes de l'approvisionnement en eau potable de la commune de Boukombé, $33 \mathrm{p}$.

26. Skold A., Cosco D.L., Klein R., (2011). Methemoglobinemia : pathogenesis, diagnosis, and management. South Med J, 104p.

27. Soro N., Ouattara L., Dongo K., Kouadio K. E., Ahoussi K. E., Soro G., Oga Y. M.-S., Savane I., Biémi J., (2010). Déchets municipaux dans le Town d'Abidjan en Côte d'Ivoire : sources potentielles de pollution des eaux souterraines. International Journal of Biological and Chemical Sciences, 4 (6): 2203-2219.

28. UNICEF (2002). Maladies courantes liées à l'eau et à l'assainissement, www.unicef.org/french/wash/index water_quality.html [07-06-15]. 